\title{
Diagnosis and treatment of mucocele in a pediatric patient: case report
}

\author{
Diagnóstico e tratamento de mucocele em paciente \\ pediátrico: relato de caso
}

\author{
Luana Santos MAGALHÃES ${ }^{1}$ iD https://orcid.org/0000-0002-0452-1562 \\ Mirian Noé do Bomfim CALAZANS1 ID https://orcid.org/0000-0001-7613-0379 \\ Ana Lídia Soares COTA 1 iD https://orcid.org/0000-0001-8220-7846 \\ Mariana Alencar NEMEZIO1 ${ }^{1}$ iD https://orcid.org/0000-0003-1852-7882 \\ Marcus Antônio BRÊDA JUNIOR ${ }^{1}$ iD https://orcid.org/0000-0001-6515-472X
}

\section{ABSTRACT}

Mucocele is a benign lesion, originating from disorders of minor salivary glands containing mucus. These lesions are found in children and young adults and usually occur due to local trauma. Clinically, it presents as a circumscribed, asymptomatic, soft and bluish or normocromic blister. The treatment of choice is surgical removal, when the lesion does not rupture naturally. This study aims to report a clinical case of mucocele in a pediatric patient removed through total surgical excision. A 7-year-old patient accompanied by mother sought care at the Dentistry Clinic of the "Tiradentes" University Center (UNIT / AL), with a main complaint of asymptomatic blister in the lower lip for about 15 days. In the anamnesis, the habit of biting in the region was reported. At clinical examination, a blister with clear limits of approximately $10 \mathrm{~mm}$ in diameter was observed in the lower lip mucosa, with slightly firm/fibrous consistency, which gave rise to doubts about the possible diagnosis, since it presented characteristics similar to that of a mucocele, although consistency at palpation indicates possible fibroma. Surgical excision of the lesion was performed; the material collected was fixed in $10 \%$ formalin and sent to histopathological examination that confirmed the diagnosis of mucocele. The patient was kept on follow-up, and there was no recurrence of the lesion. Surgical excision demonstrated an effective and prognostic therapeutic course, allowing accurate diagnosis through the histopathological evaluation of the lesion.

Indexing terms: Minor surgical procedures. Mucocele. Pediatric dentistry.

\section{RESUMO}

Mucocele é uma lesão benigna, proveniente de desordens de glândulas salivares menores, que contém muco em seu interior. Essas lesões são encontradas em crianças e adultos jovens e ocorrem, geralmente, devido a um traumatismo local. Clinicamente apresenta-se como uma bolha circunscrita, assintomática, de consistência mole e cor azulada ou normocrômica. O tratamento de escolha é a remoção cirúrgica, quando a lesão não rompe naturalmente. Objetivo: Este trabalho tem como objetivo relatar um caso clínico de mucocele em paciente pediátrico removido por meio de excisão cirúrgica total. Relato de caso: Paciente acompanhado da

\footnotetext{
$\boldsymbol{M V} \mathbf{v}$

${ }^{1}$ Centro Universitário Tiradentes, Odontologia. Av. Comendador Gustavo Paiva, 5017 - Cruz das Almas, Maceió - AL, 57038-000. Correspondence to: LS Magalhães. E-mail: <luana.s.magalhaes@hotmail.com>. 
mãe, 7 anos, procurou atendimento na Clínica de Odontologia do Centro Universitário Tiradentes (UNIT/AL), com queixa principal de aparecimento de bolha no lábio inferior, assintomática, cerca de 15 dias, na anamnese foi relatado o hábito de mordedura na região. Ao exame clínico foi observada uma bolha, com limites nítidos, de aproximadamente $10 \mathrm{~mm}$ de diâmetro, na mucosa do lábio inferior, de consistência levemente firme/fibrosa o que gerou dúvidas sobre o possível diagnóstico, pois apresentava características semelhantes à de uma mucocele apesar da consistência a palpação indicar um possível fibroma. Foi realizado a excisão cirúrgica da lesão, o material colhido foi fixado em formol a 10\% e encaminhado para exame histopatológico que confirmou o diagnóstico de mucocele. O paciente foi mantido em acompanhamento, não havendo recorrência da lesão. Conclusão: A excisão cirúrgica demonstrou-se uma conduta terapêutica eficaz e com bom prognóstico, possibilitando um diagnóstico preciso através da avaliação histopatológica da lesão.

Termos de indexação: Procedimentos cirúrgicos menores. Mucocele. Odontopediatria.

\section{INTRODUCTION}

By definition, mucoceles are considered cavities to be filled by mucus, "muco" means mucus, and "coele" means cavity $[1,2]$. Thus, mucocele is a benign oral cavity lesion involving salivary glands and ducts [2]. It can be caused by acute or chronic mechanical trauma, with bite being the most common cause due to the compression of ducts of minor salivary glands [3]. They are classified as mucus extravasation or mucus retention cyst [4]. The phenomenon of mucus extravasation is the most common type of mucocele and is related to damage to the excretory duct of the minor salivary gland (trauma and laceration), which causes mucus extravasation in the adjacent connective tissue. The mucus retention cyst appears after partial or complete obstruction of the excretory duct (for example, a calculus), which causes retention of glandular secretion and duct dilation [5]. These lesions are mainly observed in the first decades of life and have no predilection for gender [3]. The most common location is the lower lip, lateral to the midline, but may occur in other sites of the oral cavity $[5,6]$. It presents as a blister containing saliva, flaccid to palpation, of the same color as that of adjacent or bluish mucosa, asymptomatic and with smooth surface [3-7] and varied size [4,5], being able to surpass $10 \mathrm{~mm}$ in diameter $[3,5,6]$. Diagnosis is based on the previous history of the lesion and clinical characteristics, but the final diagnosis can only be determined through histopathological examination [8]. Most of mucocele lesions are of short duration, rupture and heal spontaneously; however, some are chronic in nature, requiring local surgical excision, and the total removal of the lesion and the involved gland is the ideal treatment to avoid recurrence [5-7]. Literature also indicates other options for the mucocele treatment such as cryosurgery, marsupialization and the Shira technique $[4,7,9]$. The aim of this work was to report a clinical case of mucocele of a child removed through total surgical excision of the lesion.

\section{CASE REPORT}

Male 7-year-old Caucasian patient sought care at the Dentistry Clinic of the "Tiradentes" University Center (UNIT / AL), accompanied by mother, with main complaint of onset of asymptomatic lower lip blister for about 15 days (figure 1). During anamnesis, the mother did not recall whether the child suffered any type of trauma but reported history of chronic biting in the region. She described that, at other times, the lesion appeared and regressed spontaneously. At clinical examination, a blister with clear oval-shaped borders of approximately $10 \mathrm{~mm}$ in diameter was observed in the lower lip mucosa, on the right side, with slightly firm / fibrous consistency, which generated doubts about the possible diagnosis of a smooth surface, sessile base, normochromic coloration, with characteristics

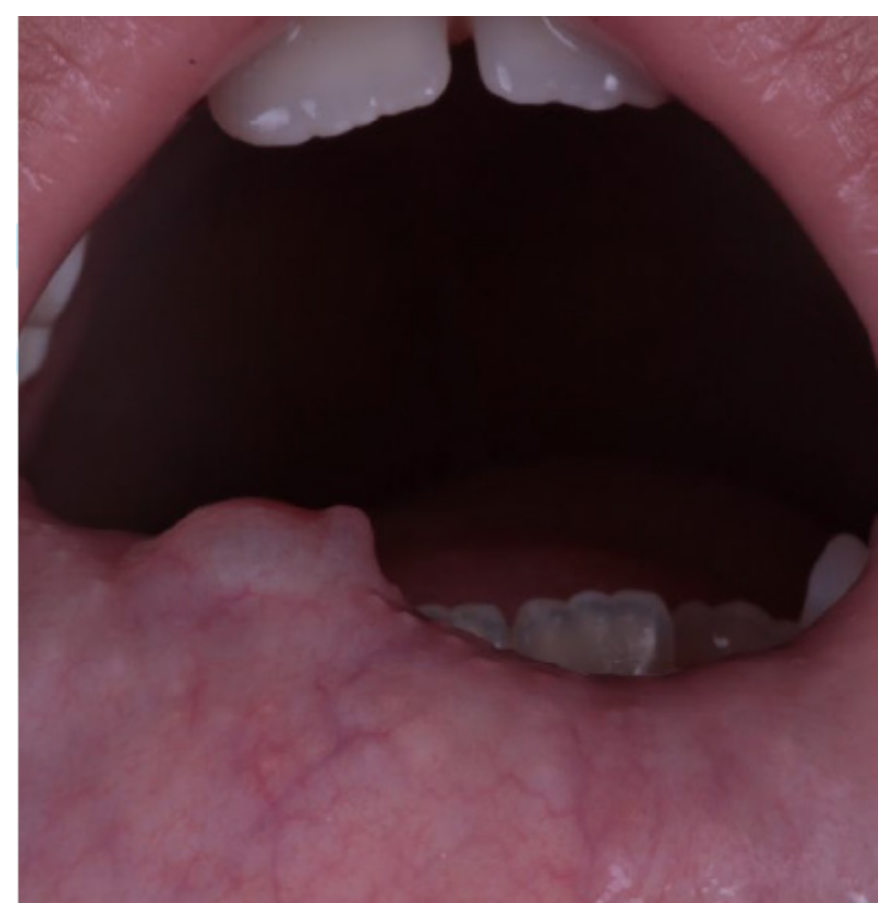

Figure 1. Initial aspect. 
similar to that of mucocele, although consistency at palpation indicates possible fibroma. In view of the clinical suspicion, the therapeutic approach adopted was total surgical removal of the lesion for histopathological evaluation. Intra- and extra-oral antisepsis of the patient with $0.1 \%$ Chlorhexidine solution and $2 \%$ Chlorhexidine, respectively, topical anesthesia and local submucosal infiltrative anesthesia with $2 \%$ Lidocaine + Epinephrine 1: 100,000 surrounding the lesion were carefully performed not to deform it. The lesion was then seized with Allis tweezers. With determined limits, scalpel blade number 15 was used for incision in the shape of an ellipse (figure 2). The tissue was divulsed, the associated accessory salivary glands were removed to prevent relapses, and tissue excision was performed. After observing the final aspect of the surgical wound (figure 3), simple suture stitches were performed with Vicryl 6-0 suture. After surgery, the patient was recommended to remain at rest, diet with pasty and cold food in the first days, cold compresses in the place in the first hours and to avoid biting the lips due to the local anesthesia to avoid trauma. Ibuprofen $100 \mathrm{mg} / \mathrm{mL}$, 20 drops, of $6 / 6$ hours for 3 days was prescribed. After

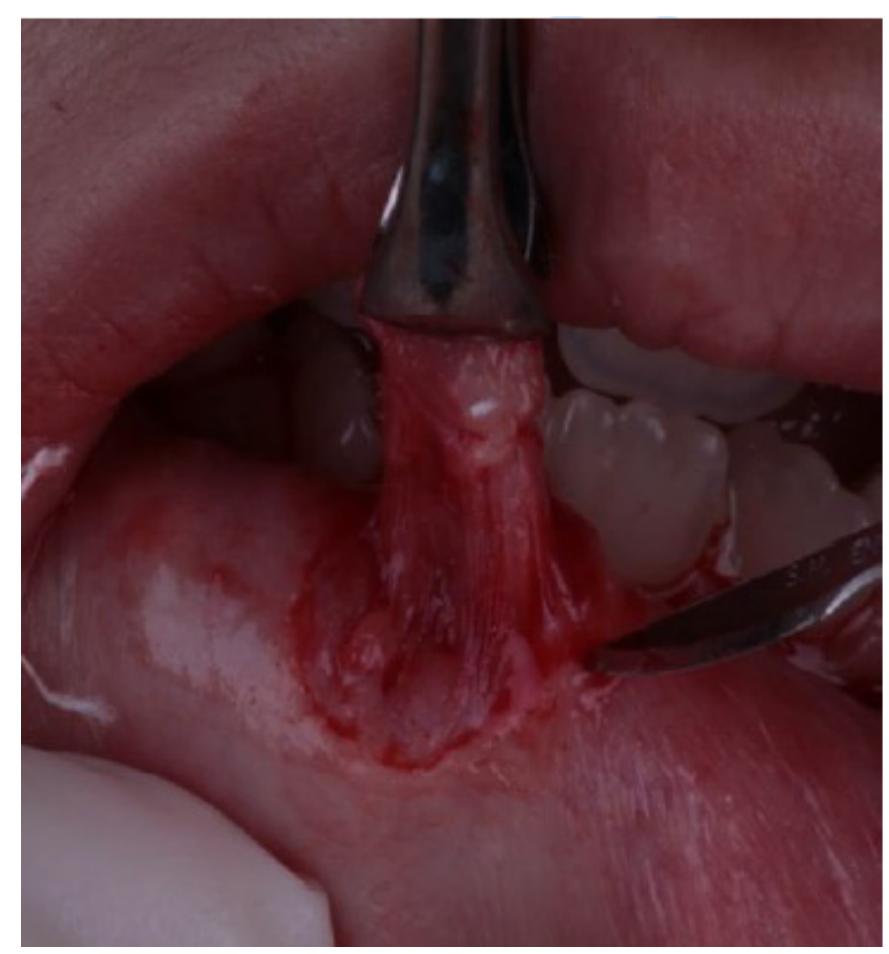

Figure 2. Incision of the lesion.
7 days, the patient returned to clinical follow-up and tissue healing was verified.

The collected material (figure 4) was fixed in 10\% formalin and sent for histopathological examination. The result revealed mucosa fragments coated with keratinized squamous epithelium presenting spongiosis with subjacent

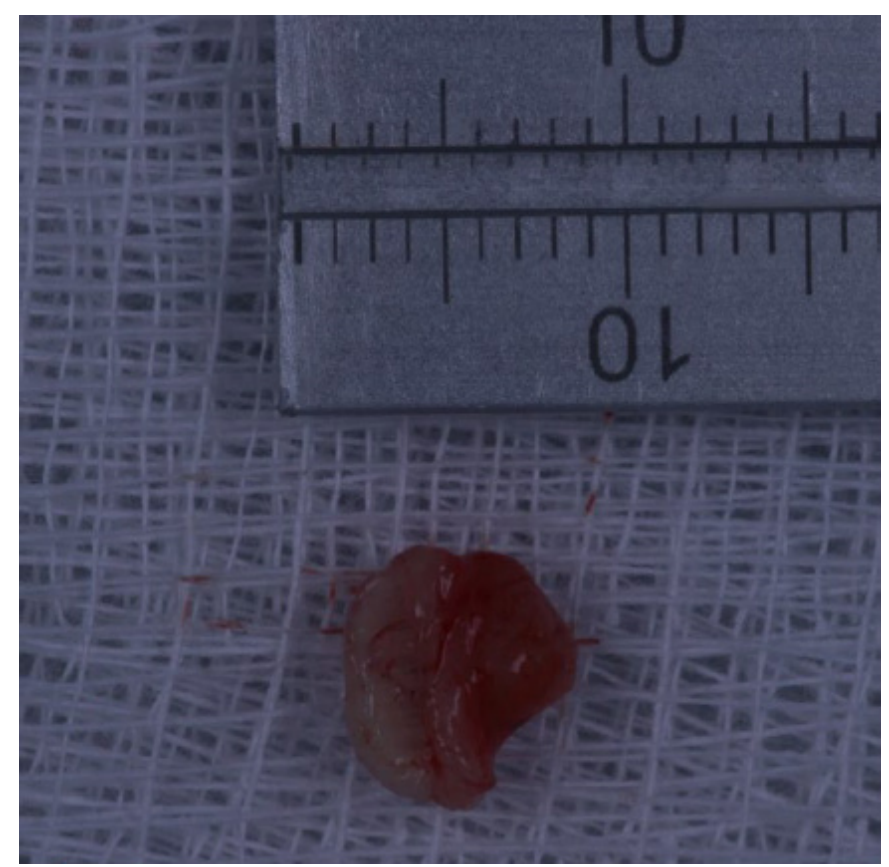

Figure 3. Tissue removed for histopathological examination.

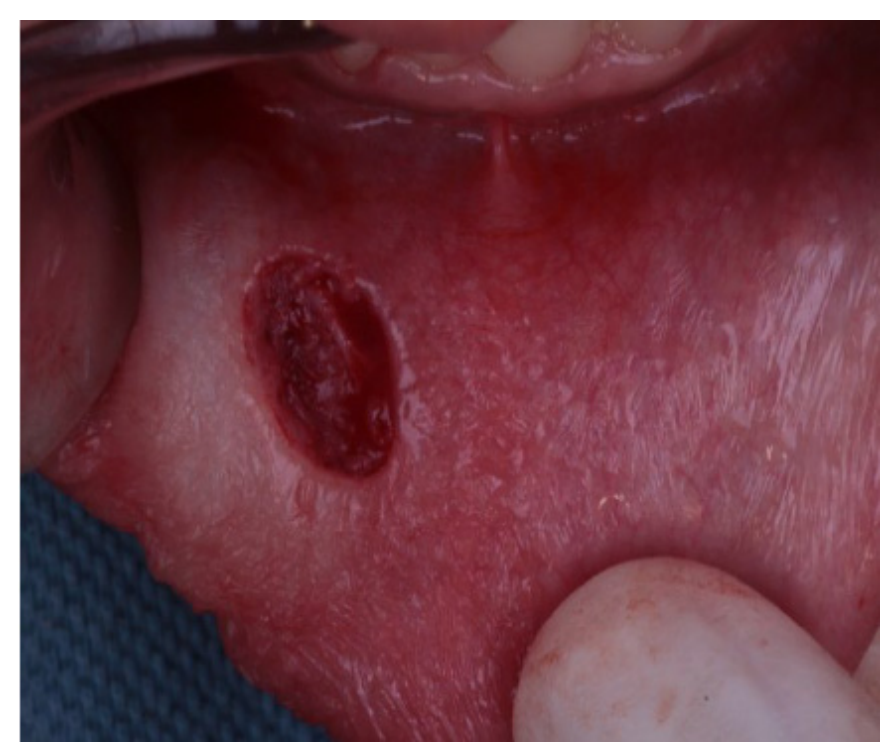

Figure 4. Aspect of surgical wound. 
fibrous connective tissue exhibiting an area of extravasated mucin associated with granulation tissue (figure 5), excluding the diagnosis of fibroma, thus confirming the diagnosis of mucus extravasation (mucocele). After eight months, the patient is under follow-up, and there is no recurrence of the lesion (figure 6).

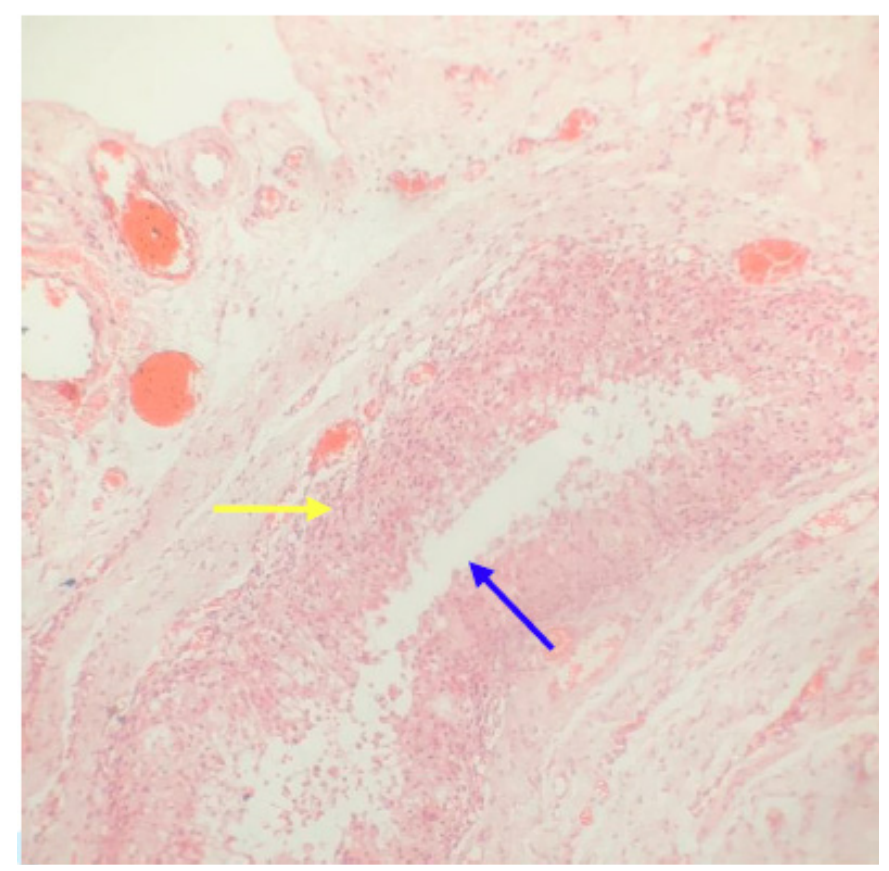

Figure 5. Area of extravasated mucin (blue arrow) associated with granulation tissue (yellow arrow), HE, 100x magnification.

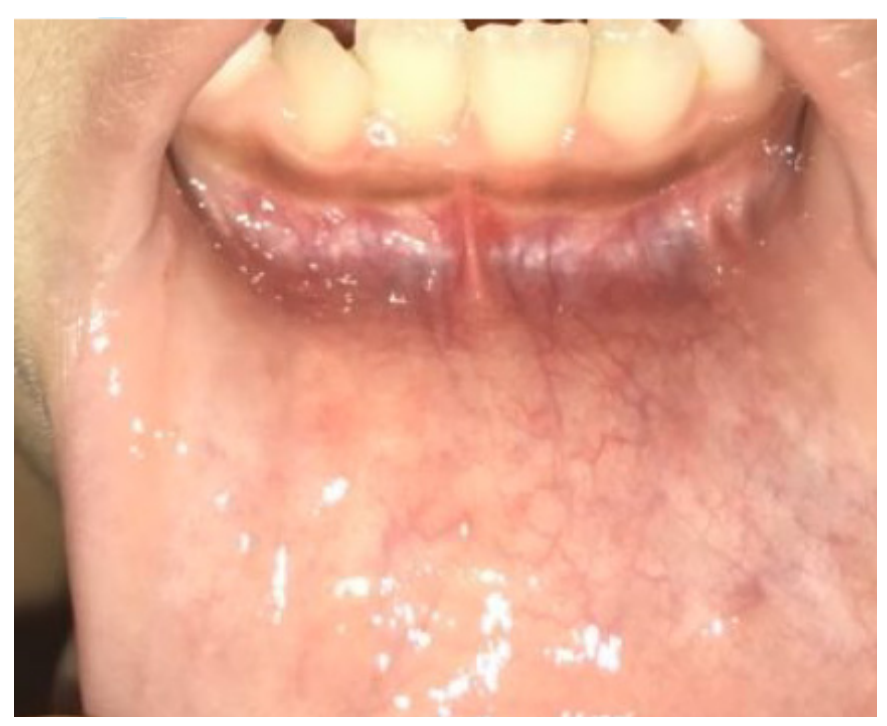

Figure 6. Prognosis: eight months after surgery, without recurrence.

\section{DISCUSSION}

Mucoceles can originate from the destruction of the excretory duct that generates the formation of an epithelium lined cyst due to the return of the mucus or from a trauma in the salivary duct, usually due to biting habits, which causes mucus to escape into adjacent tissues $[2,5,9,10,14]$. The reported clinical case corroborates literature that mucoceles are common lesions of the minor salivary glands, resulting from traumas in the salivary ducts, often due to the habit of lip biting $[1,4,5,7,9,10,11,13]$. Articles describe it as an asymptomatic lesion and show the lower lip as the most affected region $[3,5,12]$, about $60 \%$ [7] to $81 \%$ [3] of cases, which corroborates the case presented. Although this is the most frequent site of mucocele, they may also be present in other regions of the oral cavity such as: the jugal mucosa, the buccal floor, and the ventral surface of the tongue and, to a lesser extent, the upper lip $[3,5,14]$. It can occur at any age; however, according to the authors, mucoceles are more frequent in children and young adults $[1,5-7,9,11]$, as in the case of this study. There is no significant predilection for gender and its incidence is possibly related to hormonal development and emotional stress [8]. However, literature reports rare cases in which mucocele occurs congenitally due to traumas during childbirth or intrauterine digital suction [11]. The authors report that mucocele presents as a blister with salivary content, flaccid to palpation, of the same color as that of the adjacent or bluish mucosa $[5-8,10,14]$, generally exceeding $10 \mathrm{~mm}$ in diameter [1-4,6,8,12] and may rupture spontaneously with no further episodes, although recurrences are very frequent, especially if the etiologic factor remains. Clinically, it is observed that the lesion in the present clinical case differs in parts of that described in literature, because the lesion presented fibrous consistency due to subsequent traumas [9]. As in the reported clinical case, the diagnosis of mucocele is based on the previous history of the lesion and on evident clinical features; however, histopathological examination is indispensable to establish the final diagnosis [2,4-7,11-13], because during clinical examination, palpation generated doubts in the diagnosis, and histopathological examination was chosen to exclude other lesions that clinically resemble mucocele, such as fibroids, the first suspicion due to the presence of fibrous tissue and the coloration found, lipomas [6,10-13] and mucoepidermoid carcinoma [5]. The case followed treatment most indicated in literature: total surgical excision of the lesion and removal of the minor accessory glands, due 
to the possibility of performing histopathological examination and good prognosis, avoiding recurrences $[1,3,4,6-8,13,14]$. In addition to total surgical removal of the lesion, literature presents other treatment options such as marsupialization / micromarsupialization [1,2,6,7,10-12], cryosurgery [1,2,9-11], corticosteroid injection [3], diode laser removal [2] and laser vaporization $[7,10]$. In these techniques, with the exception of diode laser removal, there is no histopathological confirmation of the diagnosis due to the impossibility of collecting material $[7,11]$, in addition to the high recidivation rate [14]. Follow-up with psychologist is indicated in cases of relapses and possibility of biting habit as a result of an emotional factor, but each case should be evaluated individually [9], in the case presented in this study, the patient had no evidence of emotional stress, not being referred to a psychologist.

\section{CONCLUSION}

Among the different types of treatment for mucocele lesion, total excision of the obstructed salivary gland is the most indicated and used technique, showing to be a relatively simple and fast surgical procedure with good prognosis, being able to be carried out both by pediatric dentistry and by general practitioner, provided that there is correct diagnosis and correct indication, as in the case presented.

\section{Collaborators}

LS MAGALHÃES, bibliographic research, manuscript writing and article submission. MNB CALAZANS bibliographic research, clinical procedure and manuscript writing. ALS COTA image editing and manuscript writing. MA NEMEZIO, bibliographic research, clinical procedure supervision, manuscript writing and manuscript revision. MA BRÊDA JUNIOR work supervision.

\section{REFERENCES}

1. Stuani AS, Stuani AS, de Paula e SIlva FW, Stuani MBS, Valério RA, Queiroz AM. Mucoceles: lesões frequentes na cavidade bucal de crianças. Pediatria (São Paulo). 2010;32(4):288-292.
2. Sukhtankar LV, Mahajan B, Agarwal P. Treatment of lower lip mucocele with diode laser-A novel approach. Annals Dent Res. 2013;2(1):102-108.

3. Santos FM, Corrêa FNP, Corrêa MSNP. Mucocele em lábio inferior de adolescente: relato de caso. Rev Assoc Paul Cir. 2013;67(3):230-233.

4. Reyes VV, Diaz MC. Mucocele en el labio Inferior. Odontol Sanmarquina. 2011;14(2):29-31.

5. Mariano CV, Pikunas C, Miguel CM, Nakamura LK, Imparato JCP, Pinheiro SL. Mucocele. Rev Ciênc Méd. 2004; 13(1):77-83.

6. Castillo HAA. Uso de OK-432 (Picibanil) como alternativa no quirúrgica para el manejo de ránulas y mucoceles. Rev ADM. $2011 ; 68(5): 215-221$.

7. De Albuquerque $A C L$, Baldin JJCMC, Rodrigues FG, Soares MSM, Silva DF. Diagnóstico e tratamento de mucocele labial: relato de caso. Rev Saúde Ciênc. 2015;4(1):25-31.

8. Nascimento JS, Azevedo RS, Barros EMVB, Takahama Junior A. Mucoceles da cavidade oral: análise das características histopatológicas de 42 casos. Rev Odontol Bras Central. 2014;23(66):162-165.

9. Freitas MCA, Falcão MML, Ramos MESP, Batista TS, Santos LPS, Braga TR. Terapêutica interdisciplinar na mucocele oral: relato de caso. Rev UNINGÁ. 2012;31:105-112.

10. Alves LA, Di Nicoló R, Ramos CJ, Shintome L, Barbosa CS. Retention mucocele on the lower lip associated with inadequate use of pacifier. Dermatol J. 2010; 16(7).

11. Ansari Gh, Daneshvar S-H. Congenital Mucocele of The Lower Lip: Case Report and Literature Review. J Islam Dent Assoc Iran. 2017; 29(4):177-182. http://dx.doi.org/10.30699/ jidai.29.4.177

12. Martínez A, Arcila VG, Carmona Z. Resección quirúrgica de mucocele utilizando relleno siliconado. Salud Uninorte. 2014; 30(3):498-504.

13. Nair SS, Prakash R, Mohan V. Mucocele on the lower lip: Case Report. Global J Res Analysis. 2018; 7(5): 42. http://dx.doi. org/10.36106/gjra

14. Manfro ARG, Manfro R, Bortoluzzi MC. Mucocele em lábio inferior: relato de caso clínico. Unoesc \& Ciência - ACBS. $2011 ; 1(2): 135-140$. 